Tersedia online di: http://ejournal-balitbang.kkp.go.id/index.php/JP
e-mail:jurnalpari@gmail.com
JURNAL PARI
Volume 5 Nomor 2 Desember 2019
p-ISSN: 2502-0730
e-ISSN : 2549-0133

\title{
METODE EVALUASI KOLEKSI PERPUSTAKAAN: STUDI KASUS PEMETAAN KOLEKSI PERPUSTAKAAN SEKOLAH TINGGI PERIKANAN JAKARTA TAHUN 2017-2019
}

\author{
WIDYA INDARTI \\ Sekolah Tinggi Perikanan Jakarta, Badan Riset Dan Sumber Daya Manusia Kelautan Dan Perikanan \\ Diterima tanggal : 12 September 2019 Diterima setelah perbaikan : 28 November 2019 \\ disetujui terbit : 3 Desember 2019
}

\section{ABSTRAK}

Teknik pemetaan koleksi yang digunakan di Perpustakaan Sekolah Tinggi Perikanan (STP) Jakarta melibatkan koleksi sebagai bentuk evaluasi. Metode ini terfokus pada koleksi yang disediakan dan subjek yang dibutuhkan. Sebuah survey menggunakan kuesioner telah dilakukan untuk mengidentifikasi kekuatan dan kelemahan koleksi bidang tertentu untuk pengembangan koleksi lebih lanjut. Sepuluh Subjek tersebut, yaitu: (1) Karya Umum, (2) Subjek Filsafat dan Psikologi, (3) Subjek Agama, (4) Subjek Sosial, (5) Subjek Bahasa, (6) Subjek Ilmu Pengetahuan Alam dan Matematika, (7) Subjek Teknologi dan IImu Terapan, (8) Subjek Seni, (9) Subjek Sastra, (10) Subjek Sejarah.

KATAKUNCl: Evaluasi Koleksi; Pengembangan Koleksi; Layanan Sirkulasi.

\begin{abstract}
Collection mapping technic which used by Sekolah Tinggi Perikanan (STP) Jakarta Library modified library collections reffered to collection evaluation. This method focused to served subjet and needed. A Survey has done by using questionnaire to identify the strength and weakness of certain subject fields for future Collection Development. Ten Subjects are: (1) Generalities, (2) Philosophy and Psychology, (3) Religion, (4) Social, (5) Language, (6) Science and Mathematic, (7) Technology and Applied Sciences, (8) Art, (9) Literature, (10) History.
\end{abstract}

\section{KEYWORDS: Collection Evaluations; Collection Development; Circulation Services.}




\section{PENDAHULUAN}

\subsection{Latar Belakang}

Berdasarkan Undang-Undang Nomor 43 Tahun 2007 tentang Perpustakaan, BAB I, Pasal 1, disebutkan, bahwa: Perpustakaan adalah institusi pengelola koleksi karya tulis, karya cetak, dan/atau karya rekam secara profesional dengan sistem yang baku guna memenuhi kebutuhan pendidikan, penelitian, pelestarian, informasi dan rekreasi para pemustaka.

Kemudian, pada pasal 2 disebutkan bahwa koleksi perpustakaan adalah semua informasi dalam bentuk karya tulis, karya cetak, dan/ atau karya rekam dalam berbagai media yang mempunyai nilai pendidikan, yang dihimpun, diolah dan dilayankan.

Berdasarkan amanat Undang-undang tersebut, maka perpustakaan perlu melakukan penilaian terhadap koleksi, meningkatkan kualitasnya dan mengolahnya untuk kepentingan pemustaka. Koleksi Perpustakaan menurut (Borin \& Yi, 2008) dapat dievaluasi dengan menggunakan metode berbasis koleksi. Namun sangat berguna untuk menggabungkan model evaluasi koleksi lama dan baru dengan mengadopsi metode evaluasi untuk sumber daya cetak dikombinasikan dengan statistik penggunaan berbasis baru untuk sumber daya elektronik.

Perpustakaan STP Jakarta adalah perpustakaan khusus yang memiliki tugas pokok dan fungsi untuk menunjang dan memperlancar tugas dan fungsi instansi yang bersangkutan/ lembaga induknya. Sejalan dengan pertambahan koleksi perpustakaan yang memiliki kekhususan bidang kelautan dan perikanan di lingkungan perguruan tinggi, maka perlu dijelaskan kegiatan metode evaluasi koleksi yang mendukung layanan. Sebagai bentuk tanggung jawab pustakawan, bahwa unsur pengembangan koleksi merupakan bagian dari menilai koleksi yang dimiliki. Maka melalui tulisan ini, pustakawan mencoba menjelaskan beberapa hal yang telah dilakukan di perpustakaan dalam mempersiapkan layanan, seperti pengertian evaluasi koleksi, metode evaluasi koleksi, peta koleksi dan pemanfaatan koleksi di Perpustakaan STP Jakarta.

\subsection{PERUMUSAN MASALAH}

Berdasarkan keterangan yang telah diuraikan maka dapat dirumuskan hal-hal yang berkaitan dengan evaluasi koleksi, yaitu:

a. Koleksi yang dimiliki berdasarkan subjek

b. Tingkat Kebutuhan Pengguna Terhadap Koleksi
Sehingga pada kajian ini bertujuan untuk mengevaluasi koleksi, berdasarkan:

a. Koleksi yang dimiliki berdasarkan subjek

b. Tingkat Kebutuhan Pengguna Terhadap Koleksi

\section{METODOLOGI}

Teknik pemetaan koleksi yang digunakan di Perpustakaan STP Jakarta melibatkan koleksi sebagai bentuk evaluasi dokumen. Metode ini terfokus pada koleksi, yaitu koleksi yang dimiliki dan subjek yang diinginkan. Untuk mengevaluasi subjek yang diinginkan juga dilakukan pemeringkatan subjek yang dipilih pengguna secara kuantitatif menggunakan kuesioner tertutup dengan teknik survey. Pemetaan koleksi ini merupakan suatu proses untuk mengidentifikasi kekuatan dan kelemahan koleksi bidang tertentu di perpustakaan khusus dengan maksud untuk pengembangan koleksi lebih lanjut.

\section{PEMBAHASAN}

Evaluasi menurut (Aji B dan Sirait S, 1990) adalah suatu usaha untuk mengukur dan memberi nilai secara objektif pencapaian hasil-hasil yang yang telah direncanakan sebelumnya. (Manulang 1996) mengungkapkan evaluasi adalah membandingkan hasil pekerjaan (actual result) dengan alat pengukur (standar) yang sudah ditentukan.

Sebuah proyek pemetaan koleksi didefinisikan oleh (Bushing, 2006) sebagai batasan yang dikenakan oleh sumber daya waktu, tenaga, dan teknologi. Penilaian koleksi atau pemetaan tumbuh dari kebutuhan untuk dapat menggambarkan koleksi dengan cara lain dari pada daftar judul, sehingga membantu untuk membuat jenis alat kebutuhan yang bermanfaat terutama untuk perpustakaan besar. Pustakawan dapat mempertimbangkan bagaimana menentukan kedalaman dan luasnya koleksi mereka dengan penilaian dari koleksi yang dimiliki.

Teknik evaluasi koleksi menurut (Bushing, 2006) telah berevolusi sebagai akibat dari perubahan teknologi di perpustakaan, tetapi tujuan dan manfaatnya tetap sama, yaitu kemampuan untuk memahami kekuatan dan kelemahan sumber daya informasi.

Pengukuran tingkat keterpakaian koleksi telah dibuat standarnya dalam (International Organization for Standardization, 1998) dimana terdapat dua cara yaitu:

1. Ambil sampel secara representatif dari dokumen yang dimiliki perpustakaan, periksa dan catat apakah setiap dokumen dalam sampel sedang dipinjam atau sedang digunakan. 
2. Gunakan sistem komputer untuk menghitung jumlah dokumen yang sedang digunakan pada hari yang sama.

Berdasarkan informasi yang diperoleh bahwa, keberadaan perpustakaan pada tahun 1962 bersamaan dengan berdirinya Akademi Usaha Perikanan (AUP) yang masih dibawah Departemen Pertanian, terletak di Pasar Minggu. Pada awalnya perpustakaan AUP dikelola oleh seorang pengelola dengan fasilitas dan koleksi bahan pustaka yang sangat terbatas. Seiring dengan perubahan nama dari Akademi Usaha Perikanan menjadi Diklat Ahli Usaha Perikanan (Diklat AUP) pada tahun 1979 perpustakaan mengikuti perkembangannya yaitu dikelola oleh seorang kepala perpustakaan dan dibantu oleh 5 orang staf.

Koleksi bahan pustaka mengalami penambahan yang berasal dari :

1. Pengadaan dengan pembelian dari anggaran instansi.

2. Sumbangan dari FAO,

3. Sumbangan dari Direktorat Jenderal Perikanan berupa INFISH,

4. Sumbangan dari para alumni dan dosen.

Pada tahun 1993 Diklat AUP berubah status menjadi Sekolah Tinggi Perikanan (STP), perpustakaan pun mengalami perkembangan yang cukup berarti antara lain, bertambahnya fasilitas dan bahan pustaka, penambahan dana, pengelolaan dan jumlah koleksi terus bertambah. Sejak tahun 2004 perpustakaan STP mengalami perubahan sistem dari sistem tertutup (Close Acces), menjadi sistem terbuka (Open Acces) sampai saat ini.

Sesuai dengan visi dan misi perpustakaan, maka perannya sebagai perpustakaan khusus yaitu membantu tugas badan induk tempat perpustakaan bernaung, maka ketersediaan koleksi diutamakan untuk menunjang informasi yang dibutuhkan oleh civitas akademika dan pegawai yang berada di lingkungan STP Jakarta, sehingga subjek bahan pustaka difokuskan kepada:

- Psikologi

Pengolahan Produk

Pemerintahan

literatur

Pendidikan

Geografi

Sosial

Agama

Ekonomi

Manajemen

IImu Terapan

IImu Murni

Perikanan

Kesusastraan

Biografi

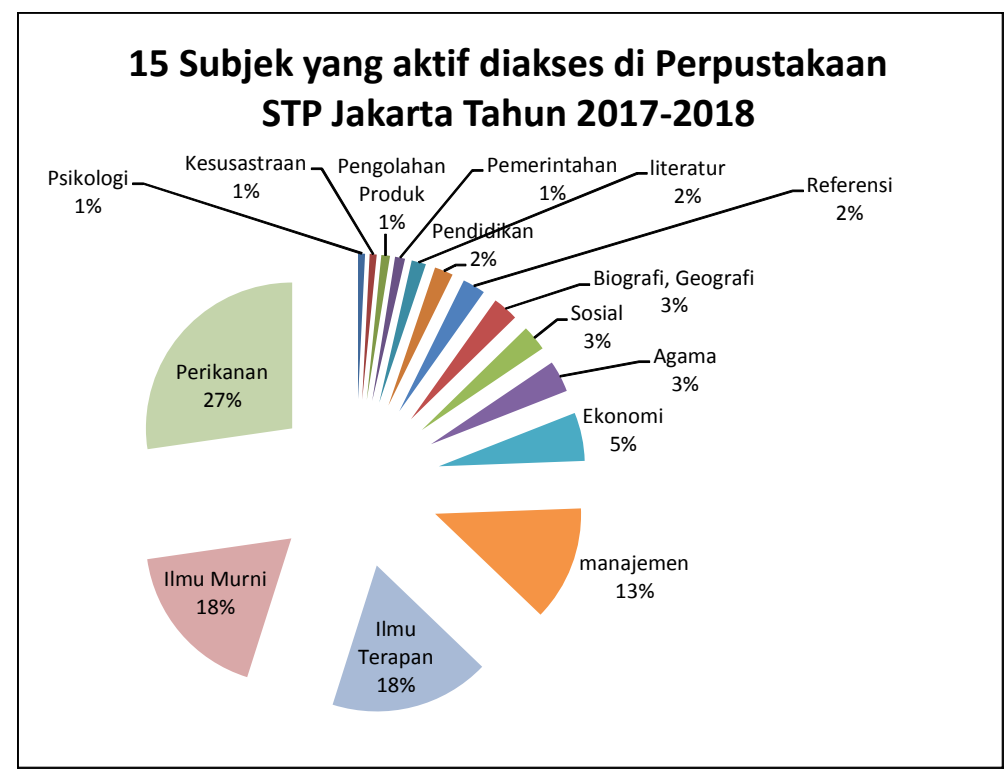

Diagram 1. Subjek-subjek yang aktif diakses di Perpustakaan STP Jakarta tahun 2017-2018

Pengadaan bahan pustaka di Perpustakaan STP Jakarta dilakukan dengan seksama yaitu sesuai dengan fungsi perpustakaan di bidang pendidikan tinggi perikanan. Jenis bahan pustaka yang diprioritaskan adalah koleksi-koleksi pada bidang ilmu murni, terapan perikanan, seperti: buku teks, referens, jurnal dan hasil penelitian (KIPA dan Tesis). Buku teks sebagai koleksi utama layanan sirkulasi memiliki aktivitas sebagai berikut: 


\section{AKTIVITAS PEMINJAMAN BUKU TEKS \\ 2017-2018}
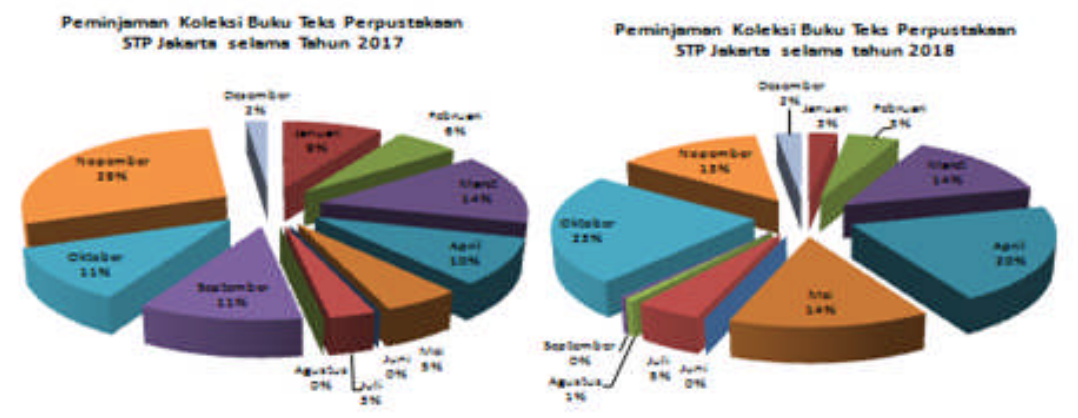

Diagram 2. Aktivitas layanan peminjaman koleksi buku teks Perpustakaan STP Jakarta selama tahun 20172018

3.1. Pemetaan koleksi berdasarkan subjek yang dimiliki

metode kuantitatif dimana pustakawan telah mengambil data pada database perpustakaan yang aktif diakses selama tahun 2017-2018 untuk tujuan

Pemetaan koleksi berdasarkan subjek yang dimiliki evaluasi. Langkah-langkah tersebut, diajukan kedalam oleh Perpustakaan STP Jakarta dilakukan dengan

Standar Operasional Prosedur adalah sebagai berikut:

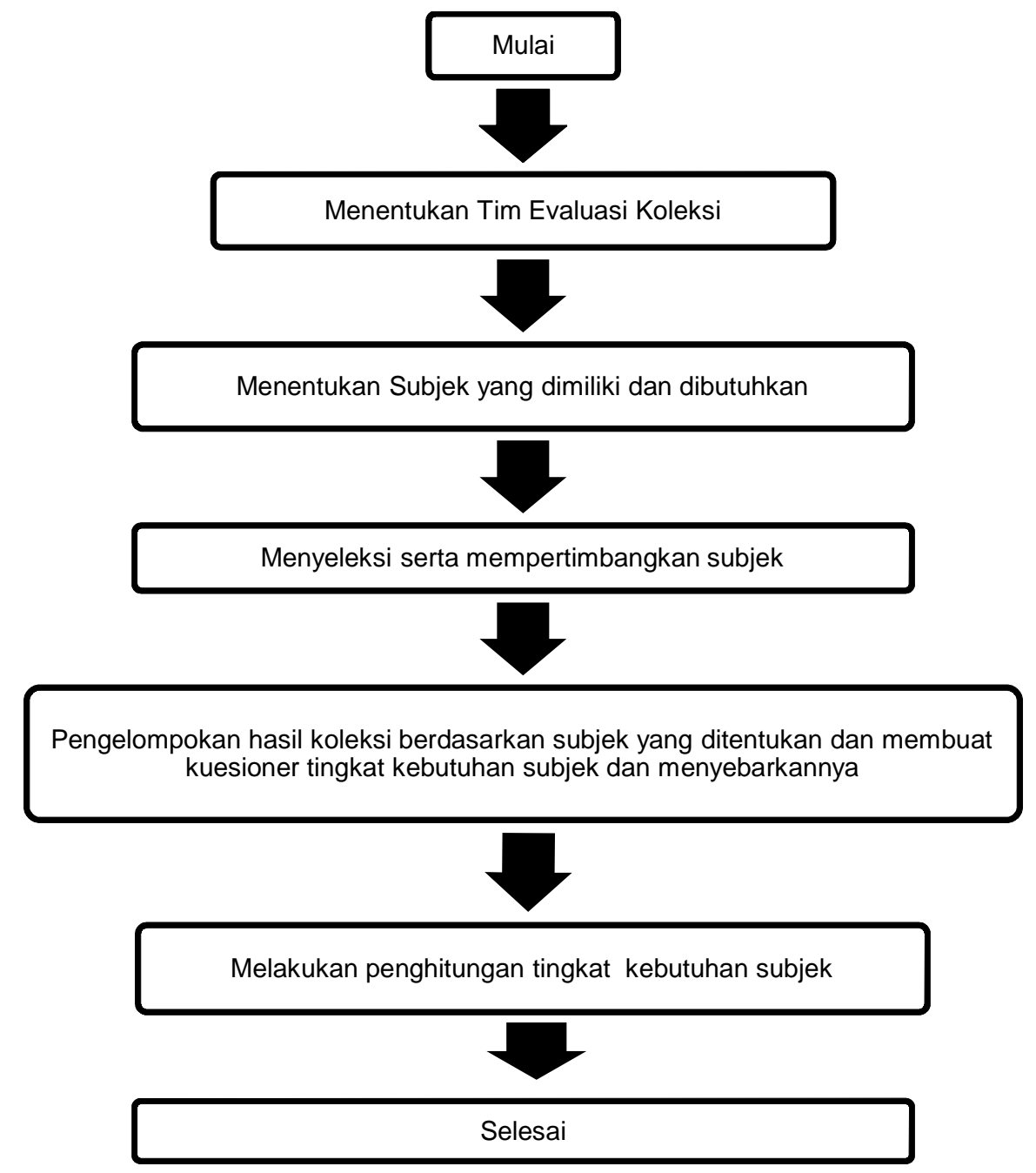

Gambar 1. Langkah-langkah kegiatan evaluasi koleksi 


\subsubsection{Menentukan Tim Evaluasi Koleksi}

Tim yang ikut serta dalam kegiatan evaluasi koleksi, terlebih dahulu didata, pada tabel sebagai berikut:

\section{Tabel 1. Tim Evaluasi Koleksi}

\begin{tabular}{|c|l|c|c|}
\hline No & \multicolumn{1}{|c|}{ Nama } & Jabatan & Keterangan \\
\hline 1. & Nunung Sabariyah & Kepala Unit & Penangung Jawab \\
\hline 2. & Widya Indarti & Pustakawan Pertama & Koordinator \\
\hline 3. & Agus Mansyur & Petugas & Anggota \\
\hline 4. & Murtani & Petugas & Anggota \\
\hline 5. & Adinda Dwi & Petugas & Anggota \\
\hline 6. & Rina Wulansari & Petugas & Anggota \\
\hline 7. & Rojali & Petugas & Anggota \\
\hline
\end{tabular}

3.1.2. Menentukan Subjek Yang Dimiliki dan Dibutuhkan

Analisis subjek bahan pustaka dilakukan sebagai salah satu kegiatan pengolahan koleksi. Analisis subjek melingkupi kegiatan sebagai berikut:

1. Menganalisis judul buku

2. Melihat kata pengantar dan daftar isi
3. Membaca sinopsis

4. Menentukan tajuk subjek

Pada saat menentukan tajuk subjek ini dapat memanfaatkan sarana bantu "Daftar Tajuk Subjek Untuk Perpustakaan" edisi revisi. Analisis subjek juga, digunakan untuk menentukan nomor klasifikasi menggunakan sarana bantu Universal Decimal Classification (UDC). Mekanisme klasifikasi UDC perlu dipahami untuk menjamin kelancaran dan ketaatazasan klasifikasi.

\subsubsection{Menyeleksi serta mempertimbangkan subjek}

Kegiatan menyeleksi dan mempertimbangkan subjek adalah suatu upaya mengumpulkan kosakata atau meringkas kebutuhan pengguna. Dari kegiatan ini diharapkan dapat ditentukan subjek subjek andalan yang dapat di prioritaskan dipajang di rak perpustakaan dari keseluruhan koleksi yang dimiliki. Ada 32 tajuk subjek yang berhasil dikelompokkan dan sangat berguna bagi pencarian informasi, yaitu sebagai berikut:

Tabel 2. Data Subjek Koleksi Yang Dimiliki Database Perpustakaan STP Jakarta

\begin{tabular}{|c|c|c|c|c|c|c|c|c|}
\hline Subjek & Penerbit & $\begin{array}{l}\text { Tahun } \\
\text { Terbit }\end{array}$ & Klasifikasi & $\begin{array}{c}\text { Tempat } \\
\text { Terbit }\end{array}$ & Pengarang & $\begin{array}{c}\text { Kode } \\
\text { Eksemplar }\end{array}$ & Identifikasi & $\begin{array}{l}\text { Nomor } \\
\text { Panggil }\end{array}$ \\
\hline $\begin{array}{l}\text { Administrasi } \\
\text { Publik }\end{array}$ & Jakarta & 1996 & $\begin{array}{l}008.006 .1 \\
\text { WAL p }\end{array}$ & Jakarta & $\begin{array}{l}<\text { Waldo, } \\
\text { Dwight }>\end{array}$ & $\begin{array}{l}<0000000 \\
016><000 \\
0000060>\end{array}$ & Buku Teks & $\begin{array}{l}008.006 . \\
1 \text { WAL p }\end{array}$ \\
\hline Agama & $\begin{array}{l}\text { Yayasan } \\
\text { Obor } \\
\text { Indonesi } \\
\text { a }\end{array}$ & 2004 & $\begin{array}{l}(7 / 8): 297.1 \\
\text { SMI i }\end{array}$ & Jakarta & $\begin{array}{l}<\text { Jane L. } \\
\text { Smith> }\end{array}$ & $\begin{array}{l}<0000000 \\
203>\end{array}$ & Buku Teks & $\begin{array}{l}(7 / 8): 297 \\
.1 \text { SMI i }\end{array}$ \\
\hline Agama & Jakarta & 1993 & $\begin{array}{l}230 / \mathrm{BAX} / \mathrm{m} \\
2\end{array}$ & Jakarta & $\begin{array}{l}\text { <Baxter, J. } \\
\text { Sidlow> }\end{array}$ & $\begin{array}{l}<0000000 \\
107>\end{array}$ & Buku Teks & $\begin{array}{l}\text { 230/BAX } \\
/ \mathrm{m} 2\end{array}$ \\
\hline Agama & Jakarta & 1995 & $\begin{array}{l}230 / \mathrm{BAX} / \mathrm{m} \\
3\end{array}$ & Jakarta & $\begin{array}{l}\text { <Baxter, J. } \\
\text { Sidlow> }\end{array}$ & $\begin{array}{l}<0000000 \\
108>\end{array}$ & Buku Teks & $\begin{array}{l}230 / \mathrm{BAX} \\
/ \mathrm{m} 3\end{array}$ \\
\hline dst. & & & & & & & & \\
\hline
\end{tabular}




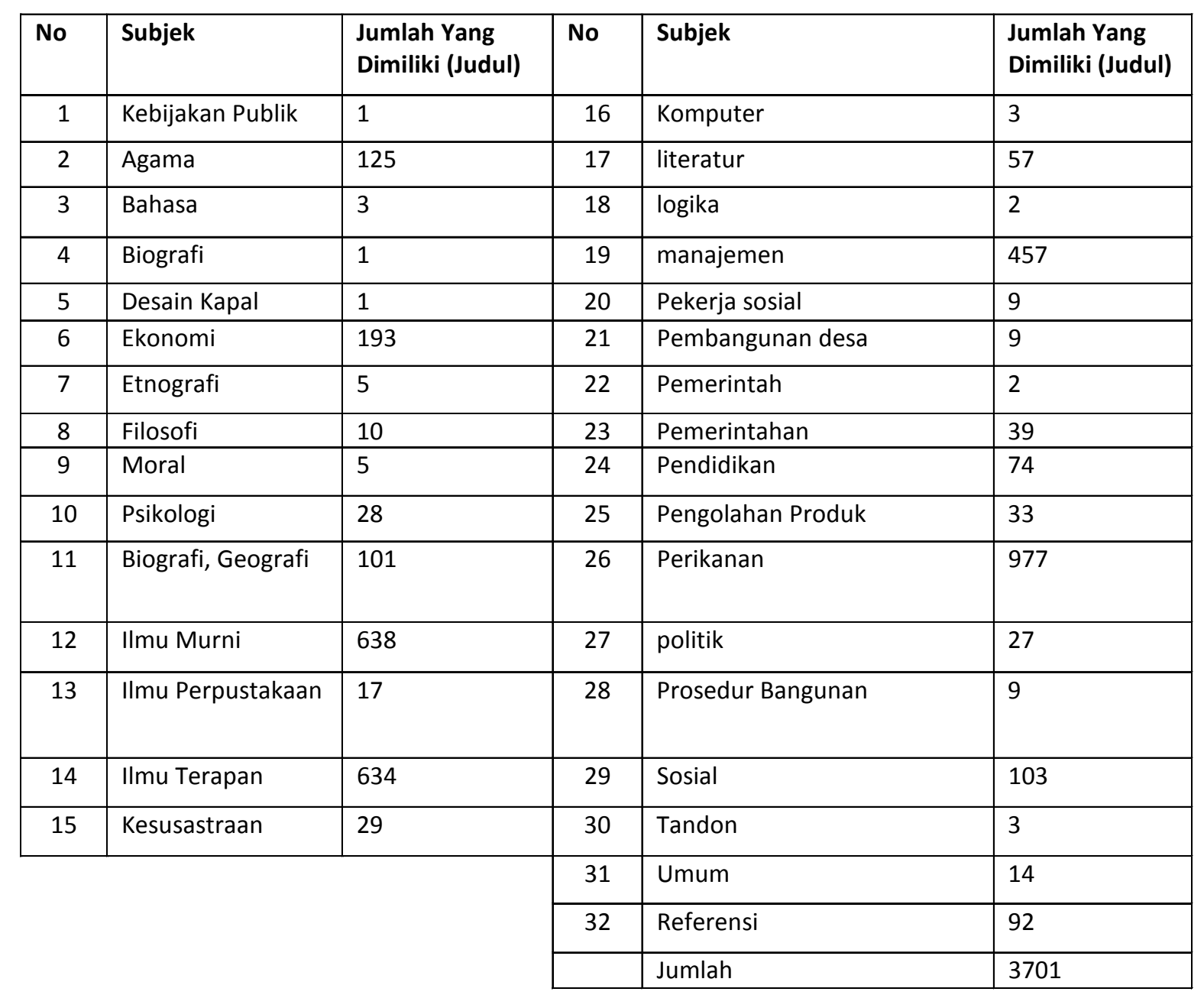

3.1.4. Pengelompokan hasil koleksi berdasarkan subjek yang ditentukan dan membuat kuesioner tingkat kebutuhan subjek

Meskipun telah didapatkan 32 tajuk subjek prioritas dalam penelusuran informasi dii perpustakaan, pustakawan tetap membuat daftar subjek lengkap, untuk mengumpulkan pendapat pengguna melalui metode survey. Daftar subjek lengkap inimenjadi kuesioner tertutup yang diisi oleh pengguna pada kurun waktu tertentu semisal 1-3 bulan kunjungan, sehingga didapatkan kecenderungan pilihan subjek secara random. Kegiatan survey tingkat kebutuhan subjek ini, telah dilakukan selama bulan April-Juni 2019. Hasil survey tingkat kebutuhan subjek merupakan permintaan dalam kurun waktu tertentu dan sifatnya temporal. Pustakawan berupaya membuat selengkap mungkin daftar subjek menggunakan alat bantu bagan klasifikasi persepuluhan.

Tabel 3. Data Subjek Yang Diinginkan untuk Dimiliki Perpustakaan

\begin{tabular}{|c|l|c|}
\hline NO & \multicolumn{1}{|c|}{ JENIS BAHAN BACAAN } & PILIHAN \\
\hline I & 000-099 KARYA UMUM & \\
\hline 1. & Buku tentang ilmu komputer, informasi dan sistem & \\
\hline 2 & Majalah dan jurnal & \\
\hline 3 & Koran dan berita jurnalisme & \\
\hline 4 & Macam- macam ensiklopedia & \\
\hline 5 & Manuskrip dan Buku Langka & \\
\hline 6 & Buku-buku tentang fakta & \\
\hline II & $\mathbf{1 0 0 - 1 9 9}$ FILSAFAT DAN PSIKOLOGI & \\
\hline 1 & Buku tentang Filsafat & \\
\hline 2 & Buku tentang Metafisika & \\
\hline 3 & Buku tentang Epistimologi & \\
\hline
\end{tabular}




\begin{tabular}{|c|c|c|}
\hline 4 & Buku tentang IImu jiwa & \\
\hline 5 & Buku tentang Psikologi & \\
\hline 6 & Buku tentang Logika & \\
\hline III & 200-299 AGAMA & \\
\hline 1 & Buku tentang agama Islam & \\
\hline 2 & Buku tentang agama Kristen & \\
\hline 3 & Buku tentang agama Katolik & \\
\hline 4 & Buku tentang agama Budha & \\
\hline 5 & Buku tentang agama Hindu & \\
\hline IV & 300-399 ILMU SOSIAL & \\
\hline 1 & Buku tentang ilmu sosial, sosiologi dan antropolgi & \\
\hline 2 & Buku tentang statistik & \\
\hline 3 & Buku tentang ilmu politik & \\
\hline 4 & Buku tentang ekonomi & \\
\hline 5 & Buku tentang hukum & \\
\hline 6 & Buku tentang administrasi publik & \\
\hline 7 & Buku tentang ilmu kemiliteran & \\
\hline 8 & Buku tentang administrasi bisnis & \\
\hline 8 & Buku tentang pendidikan & \\
\hline 9 & Buku tentang perdagangan,komunikasi dan transportasi & \\
\hline 10 & Buku tentang norma, etika dan tradisi & \\
\hline V & 400-499 BAHASA & \\
\hline 1 & Buku tentang filsafat bahasa & \\
\hline 2 & Kamus-kamus & \\
\hline 3 & Buku linguistik & \\
\hline 4 & Buku etimologi & \\
\hline 5 & Buku fonologi dan fonetik & \\
\hline 6 & Buku tentang ilmu bahasa inggris & \\
\hline 7 & Buku tentang ilmu bahasa perancis & \\
\hline 8 & Nuku tentang ilmu bahasa jerman & \\
\hline 9 & Buku tentang ilmu bahasa lainnya & \\
\hline VI & 500-599 ILMU PENGATAHUAN ALAM DAN MATEMATIKA & \\
\hline 1 & Buku tentang sejarah alam & \\
\hline 2 & Buku tentang matematika & \\
\hline 3 & Buku tentang astronomi & \\
\hline 4 & Buku tentang ilmu fisika & \\
\hline 5 & Buku tentang ilmu kimia & \\
\hline 6 & Buku tentang ilmu bumi/geologi & \\
\hline 7 & Buku tentang ekologi & \\
\hline 8 & Buku tentang biologi & \\
\hline 9 & Buku tentang ilmu pentahuan lainnya & \\
\hline VII & 600-699 TEKNOLOGI DAN ILMU TERAPAN & \\
\hline 1 & Buku tentang teklonogi secara umum & \\
\hline 2 & Buku tentang kedokteran dan kesehatan & \\
\hline 3 & Buku tentang ilmu rekayasa & \\
\hline 4 & Buku pertanian,peternakan dan ilmu terapannya & \\
\hline 5 & Buku tentang kerampilan dan manajemen rumah tangga & \\
\hline 6 & Buku tentang manajemen dan public relations & \\
\hline 7 & Buku tentang teknik kimia & \\
\hline 8 & Buku tentang teknik manufaktur & \\
\hline 9 & Buku tentang teknik bangunan dan konstruksi & \\
\hline VIII & 700-799 SENI DAN REKREASI & \\
\hline 1 & Buku tentang seni secara umum & \\
\hline 2 & Buku tentang lanscaping dan perencaan wilayah & \\
\hline 3 & Buku tentang arsitektur & \\
\hline 4 & Buku tentang seni patung,keramik dan logam & \\
\hline
\end{tabular}




\begin{tabular}{|c|l|l|}
\hline 5 & Buku tentang seni dekoratif & \\
\hline 6 & Buku tentang seni lukisan & \\
\hline 7 & Buku tentang seni grafis & \\
\hline 8 & Buku tentang fotografi dan aplikasi seni di komputer & \\
\hline 9 & Buku tentang seni musik & \\
\hline 10 & Buku tentang olahraga,permainan dan hiburan & \\
\hline IX & 800-899 SASTRA & \\
\hline 1 & Buku tentang literatur sastra & \\
\hline 2 & Buku tentang puisi & \\
\hline 3 & Buku tentang drama (teater,film dsb) & \\
\hline 4 & Buku tentang fiksi (cerita dewasa cerita anak, cerpen, komik, novel dsb ) & \\
\hline 5 & Buku tentang humor jenaka & \\
\hline 6 & Buku tentang esay & \\
\hline 7 & Buku tentang pidato & \\
\hline $\mathbf{X}$ & 900-999 SEJARAH & \\
\hline 1 & Buku tentang sejarah & \\
\hline 2 & Buku tentang geografi dan travel & \\
\hline 3 & Buku tentang biografi, autoboigrafi dan silsilah & \\
\hline 4 & Buku tentang sejarah dunia kuno & \\
\hline 5 & Buku tentang sejarah negara-negara eropa & \\
\hline 6 & Buku tentang sejarah negara-negara asia & \\
\hline 7 & Buku tentang sejarah negara-negara afrika & \\
\hline 8 & Buku tentang sejarah negara-negara amerika utara (USA,Kanada ) & \\
\hline 9 & Buku tentang sejarah negara-negara amerika selatan (amerika latin) & \\
\hline 10 & Buku tentang sejarah Negara-negara lainya & \\
\hline
\end{tabular}

3.1.5 Melakukan penghitungan tingkat kepemilikan/ kebutuhan subjek

Tahapan terakhir dari kegiatan evaluasi koleksi adalah mendapatkan gambaran koleksi yang dimiliki perpustakaan dan tingkat kebutuhan pembaca terhadap subjek tertentu.Melalui kegiatan ini juga dapat diketahui, subjek-subjek yang tidak berkembang atau tidak senantiasa disediakan/ diminta pembaca di perpustakaan. Berikut ini adalah 10 subjek yang cenderung senantiasa disediakan dan diminta pembaca selama tahun 2019:

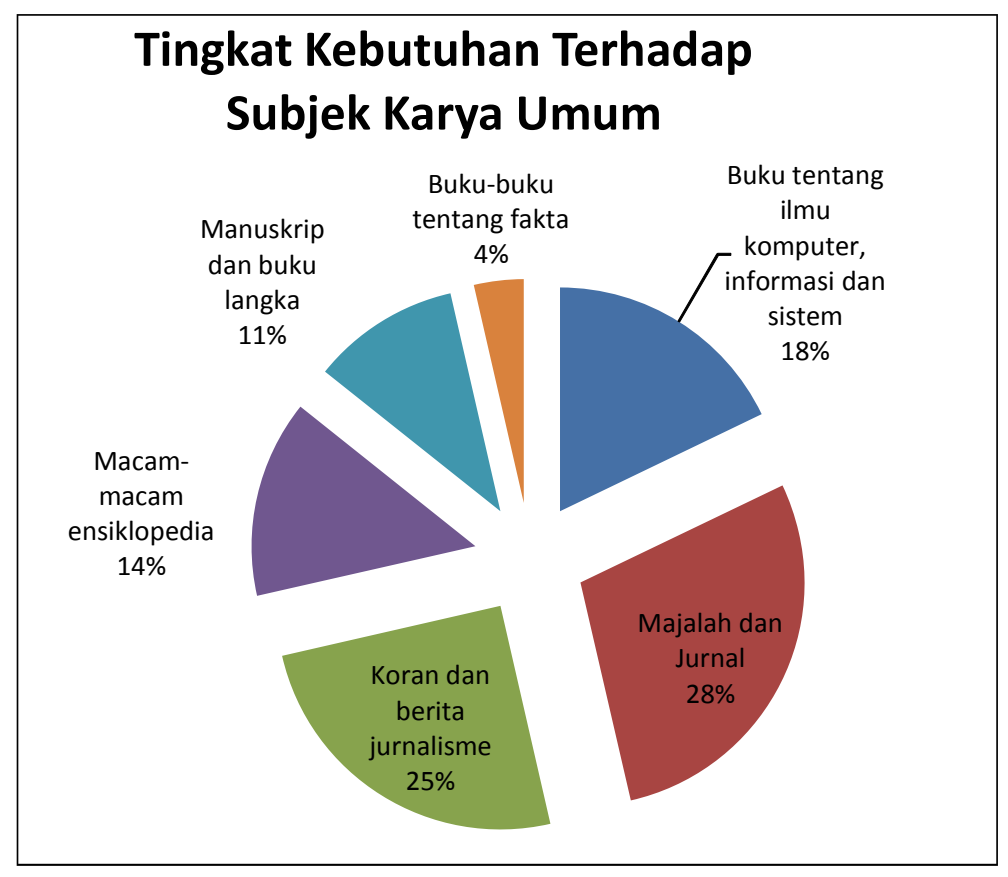

Diagram 3. Tingkat Kebutuhan Terhadap Subjek Karya Umum 


\subsubsection{Tingkat Kebutuhan Terhadap Subjek Karya Umum}

Subjek karya umum melingkupi beberapa sub subjek, dengan tingkat kebutuhan tertinggi pada majalah dan jurnal, sebesar 28 persen (\%). Urutan kedua searah jarum jam adalah koran dan berita jurnalisme sebanyak 25 persen (\%), urutan ketiga adalah buku tentang ilmu komputer, informasi dan sistem sebanyak 18 persen (\%), urutan keempat adalah buku tentang macam-macam ensiklopedia sebanyak 14 persen (\%), urutan kelima adalah manuskrip dan buku langka sebanyak 6 persen (\%), kemudian urutan kelima adalah buku-buku tentang fakta sebanyak 4 persen (\%).

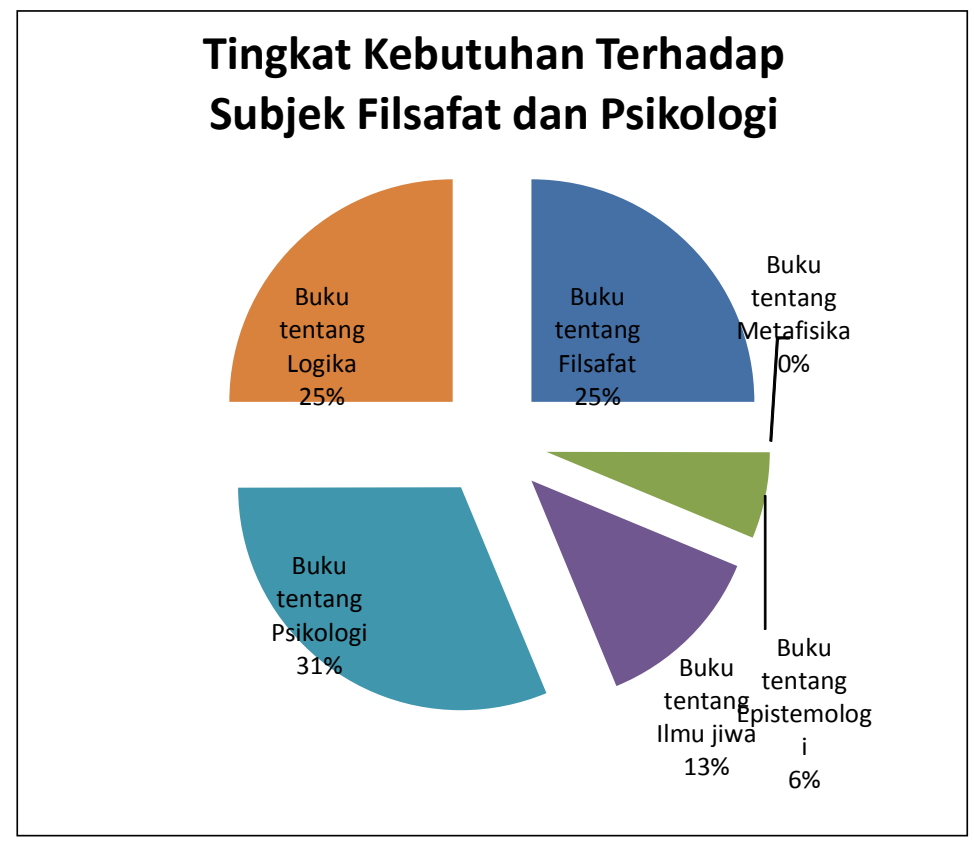

Diagram 4. Tingkat Kebutuhan Terhadap Subjek Filsafat dan Psikologi

3.1.5.2 Tingkat Kebutuhan Terhadap Subjek Filsafat dan Psikologi

Subjek filsafat dan psikologi melingkupi beberapa sub subjek, dengan tingkat kebutuhan tertinggi pada buku-buku tentang psikologi, sebesar 31 persen (\%). Urutan kedua searah jarum jam adalah buku tentang logika dan filsafat sebanyak 25 persen (\%), urutan ketiga adalah buku tentang ilmu jiwa sebanyak 13 persen (\%), urutan keempat adalah buku tentang epistemologi sebanyak 6 persen (\%), urutan kelima adalah metafisika, meski tersedia belum ada yang berminat.

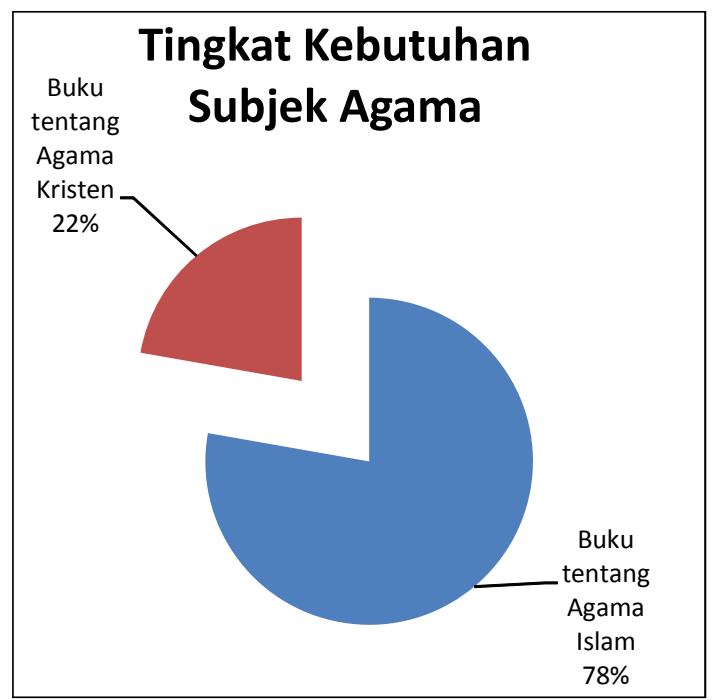

Diagram 5. Tingkat Kebutuhan Terhadap Subjek Agama 


\subsubsection{Tingkat Kebutuhan Terhadap Subjek Agama}

Kecenderungan senantiasa disediakan dan diminta pembaca disebut tingkat kebutuhan subjek yang digambarkan dalam diagram lingkaran dengan persentase angka sebagai pembeda. Tingkat kebutuhan terhadap subjek Agama hanya ada 2 pilihan teratas, Islam adalah 78 persen (\%) dan terendah adalah subjek agama Kristen sebanyak 22 persen (\%).

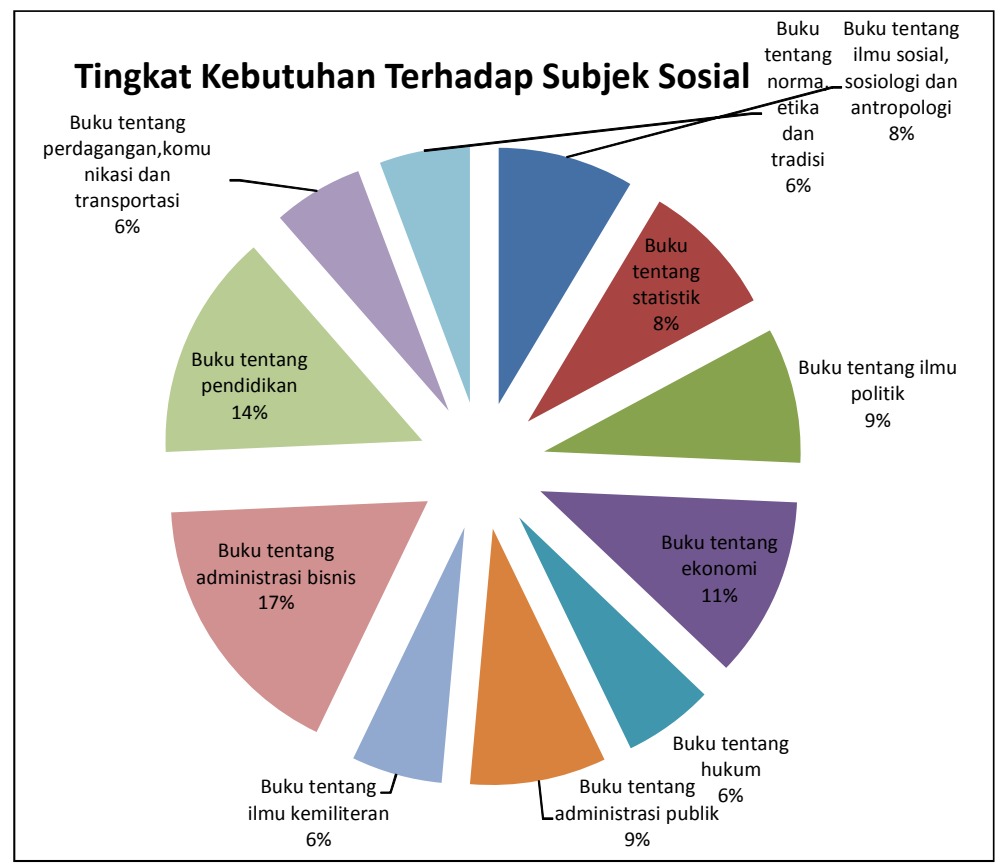

Diagram 5. Tingkat Kebutuhan Terhadap Subjek Sosial

\subsubsection{Tingkat Kebutuhan Subjek Sosial}

Subjek sosial melingkupi beberapa sub subjek, dengan tingkat kebutuhan tertinggi pada buku-buku tentang administrasi bisnis, sebesar 17 persen (\%). Urutan kedua searah jarum jam adalah buku tentang pendidikan sebanyak 14 persen (\%), urutan ketiga adalah buku tentang ekonomi sebanyak 11 persen (\%), urutan keempat adalah buku tentang IImu Politik dan Administrasi Publik sebanyak 9 persen (\%), urutan kelima adalah buku tentang ilmu sosial, sosiologi dan antropologi serta tentang statistik sebanyak 8 persen (\%), Urutan keenam ada 4 sub subjek dengan tingkat kebutuhan masing-masing enam persen (\%), yaitu: buku tentang perdagangan, komunikasi dan transportasi, buku tentang norma, etika dan tradisi serta buku tentang ilmu kemiliteran.

\subsubsection{Tingkat Kebutuhan Subjek Bahasa}

Subjek bahasa melingkupi beberapa sub subjek, dengan tingkat kebutuhan tertinggi pada buku-buku tentang ilmu bahasa Inggris, sebesar 23 persen (\%). Urutan kedua searah jarum jam adalah buku tentang fonologi dan fonetik sebanyak 15 persen (\%), urutan ketiga adalah buku tentang ilmu bahasa lainnya sebanyak 12 persen (\%), urutan keempat adalah buku tentang Filsafat bahasa dan kamus-kamus sebanyak 11 persen (\%), urutan kelima adalah buku tentang ilmu bahasa Jerman, ilmu Bahasa Perancis dan linguistik sebanyak 8 persen (\%), Urutan keenam adalah buku etimologi 4 persen (\%). 


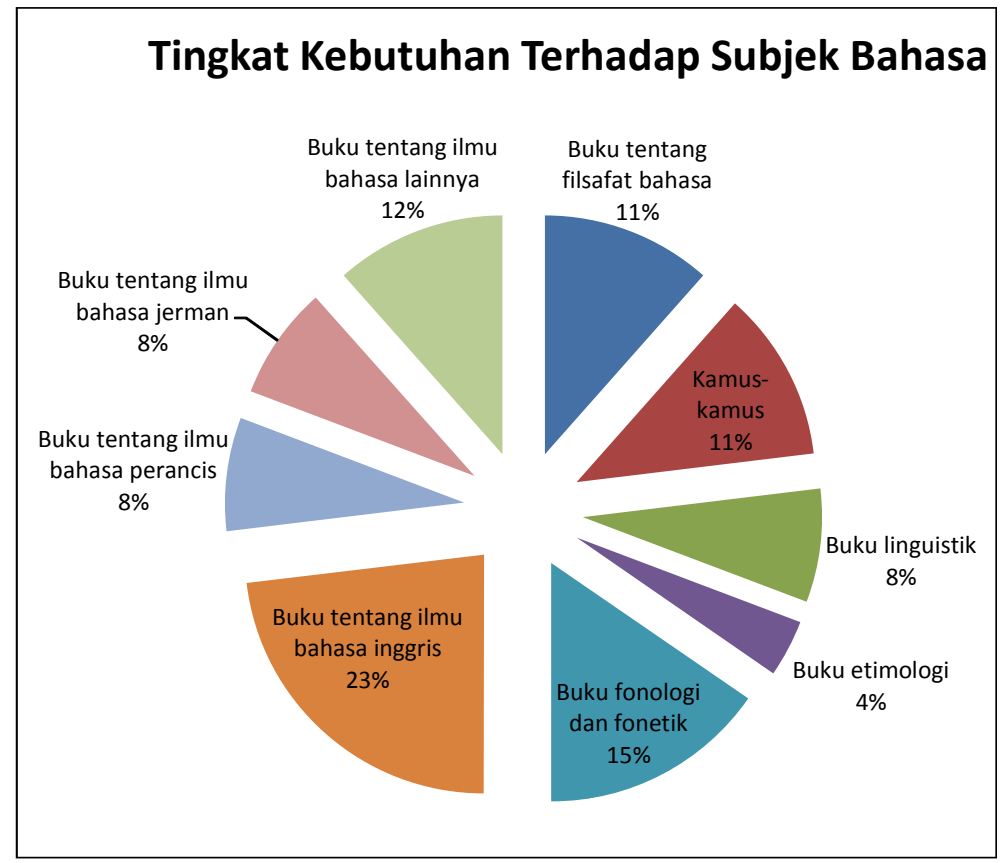

Diagram 6. Tingkat Kebutuhan Terhadap Subjek Bahasa

\subsubsection{Tingkat Kebutuhan Subjek Ilmu Pengetahuan} Alam dan Matematika

Subjek IImu Pengetahuan Alam dan Matematika melingkupi beberapa sub subjek, dengan tingkat kebutuhan tertinggi pada buku-buku tentang Biologi, sebesar 15 persen (\%). Urutan kedua searah jarum jam adalah buku tentang matematika dan kimia sebanyak 13 persen (\%), urutan ketiga adalah buku tentang ilmu fisika, astronomi, sejarah alam dan ilmu pengetahuan lainnya sebanyak 10 persen (\%), urutan keempat adalah buku tentang ekologi dan geologi sebanyak 8 persen (\%).

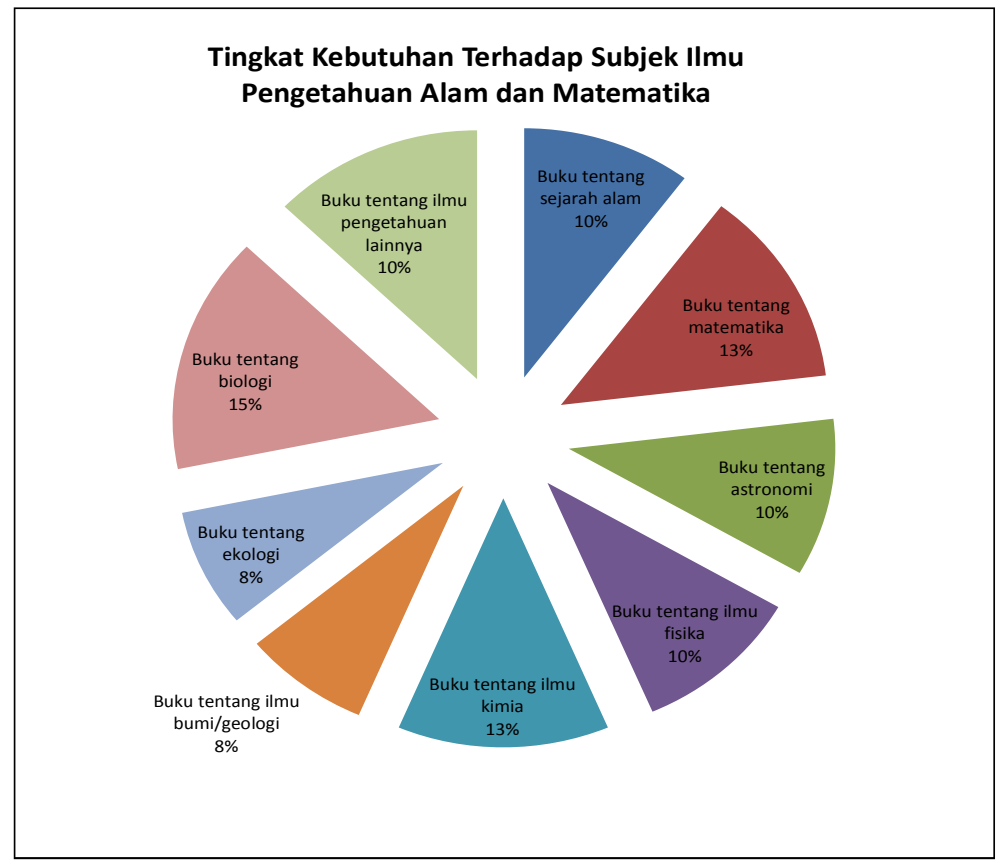

Diagram 7. Tingkat Kebutuhan Terhadap Subjek IImu Pengetahuan Alam dan Matematika 


\subsubsection{Tingkat Kebutuhan Subjek Teknologi dan IImu Terapan}

Subjek Teknologi dan IImu Terapan melingkupi beberapa sub subjek, dengan tingkat kebutuhan tertinggi pada buku-buku tentang pertanian, peternakan dan ilmu terapan lainnya sebesar 24 persen (\%). Urutan kedua searah jarum jam adalah buku tentang teknik kimia sebanyak 21 persen (\%), urutan ketiga adalah buku tentang teknologi secara umum sebanyak 17 persen (\%), urutan keempat adalah buku tentang teknik manufaktur sebanyak 14 persen (\%) dan urutan kelima adalah buku tentang kedokteran dan kesehatan sebanyak 10 persen (\%). Sedangkan buku tentang ilmu rekayasa, manajemen dan Public Relations, hanya sebesar 7 persen saja peminatnya. Sementara buku tentang keterampilan dan manajemen rumah tangga belum dipilih/ diminati.

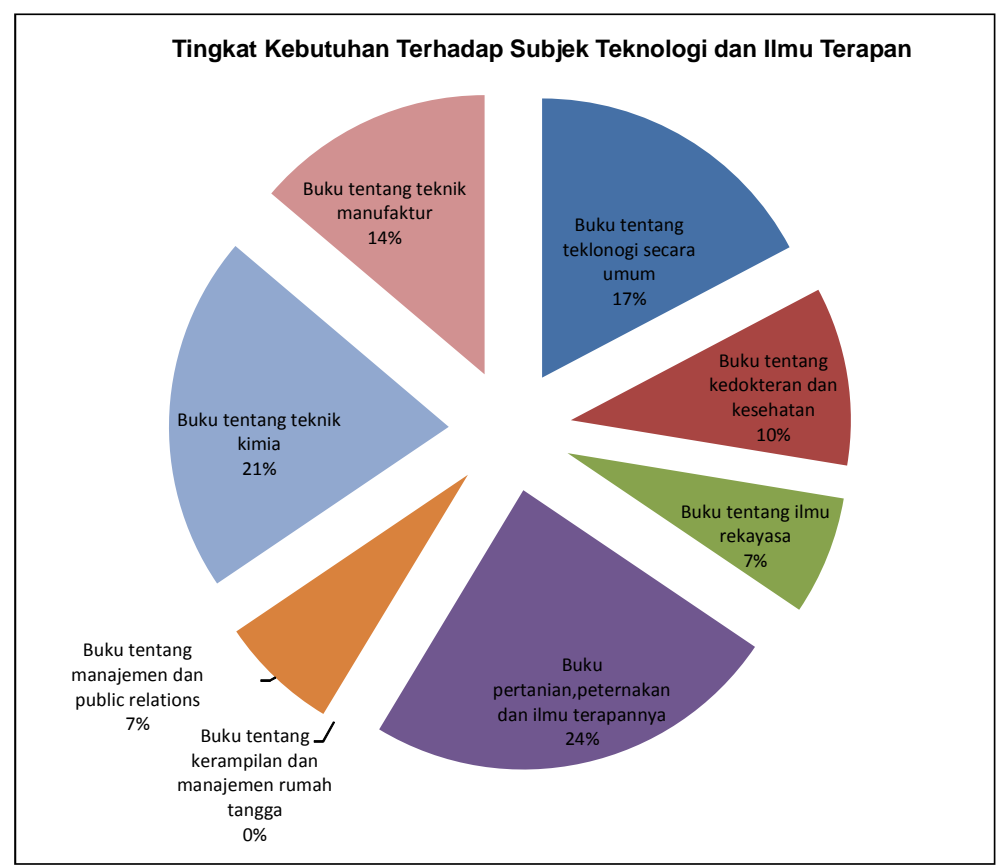

Diagram 8. Tingkat Kebutuhan Terhadap Subjek Teknologi dan IImu Terapan

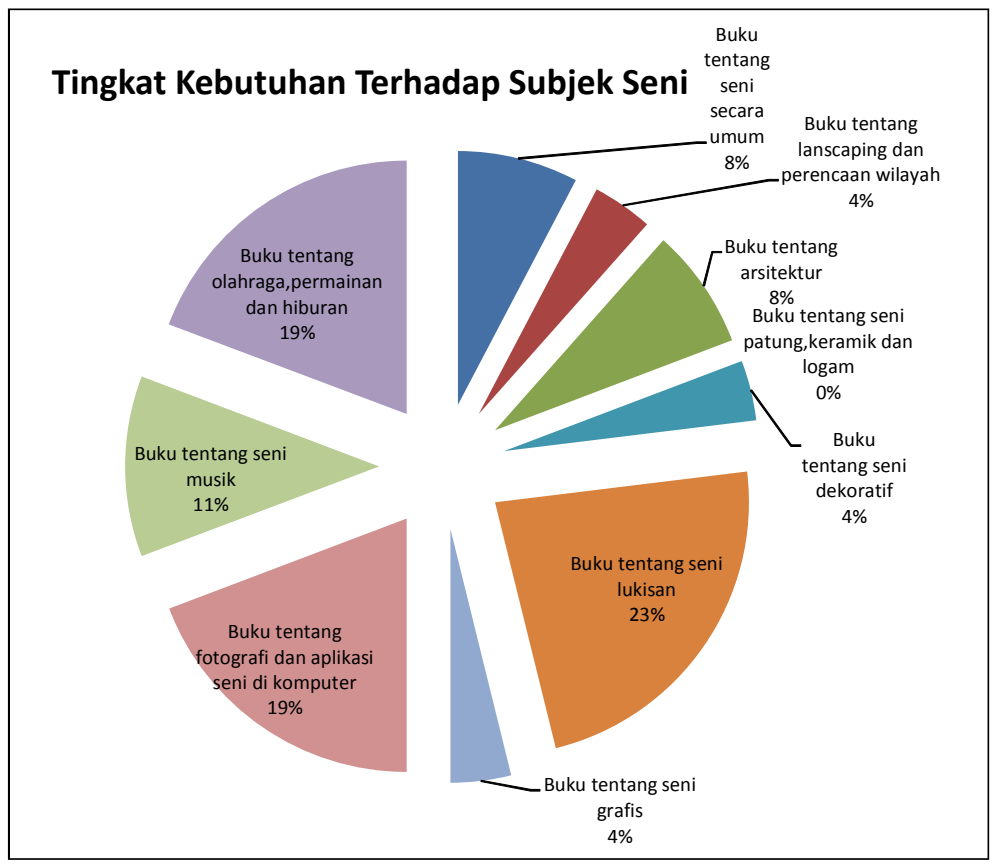

Diagram 9. Tingkat Kebutuhan Terhadap Subjek Seni 


\subsubsection{Tingkat Kebutuhan Subjek Seni}

Subjek Seni melingkupi beberapa sub subjek, dengan tingkat kebutuhan tertinggi pada buku-buku tentang seni lukisan sebanyak 23 persen (\%). Urutan kedua searah jarum jam adalah buku tentang fotografi dan olahraga sebanyak 19 persen (\%), urutan ketiga adalah buku tentang seni musik sebanyak 11 persen (\%), urutan keempat adalah buku tentang seni secara umum dan arsitektur sebanyak 8 persen (\%) dan urutan kelima adalah buku tentang landscaping, seni dekoratif dan seni grafis sebanyak 4 persen (\%). Sementara buku tentang seni patung, keramik dan logam belum dipilih/ diminati.

\subsubsection{Tingkat Kebutuhan Subjek Sastra}

Subjek Sastra melingkupi beberapa sub subjek, dengan tingkat kebutuhan tertinggi pada buku-buku tentang literatur sastra sebanyak 25 persen (\%). Urutan kedua searah jarum jam adalah buku tentang essay sebanyak 20 persen (\%), urutan ketiga adalah buku tentang pidato dan drama sebanyak 15 persen (\%), urutan keempat adalah buku fiksi dan puisi sebanyak 10 persen (\%) dan urutan kelima adalah buku tentang humor jenaka sebanyak 4 persen (\%).

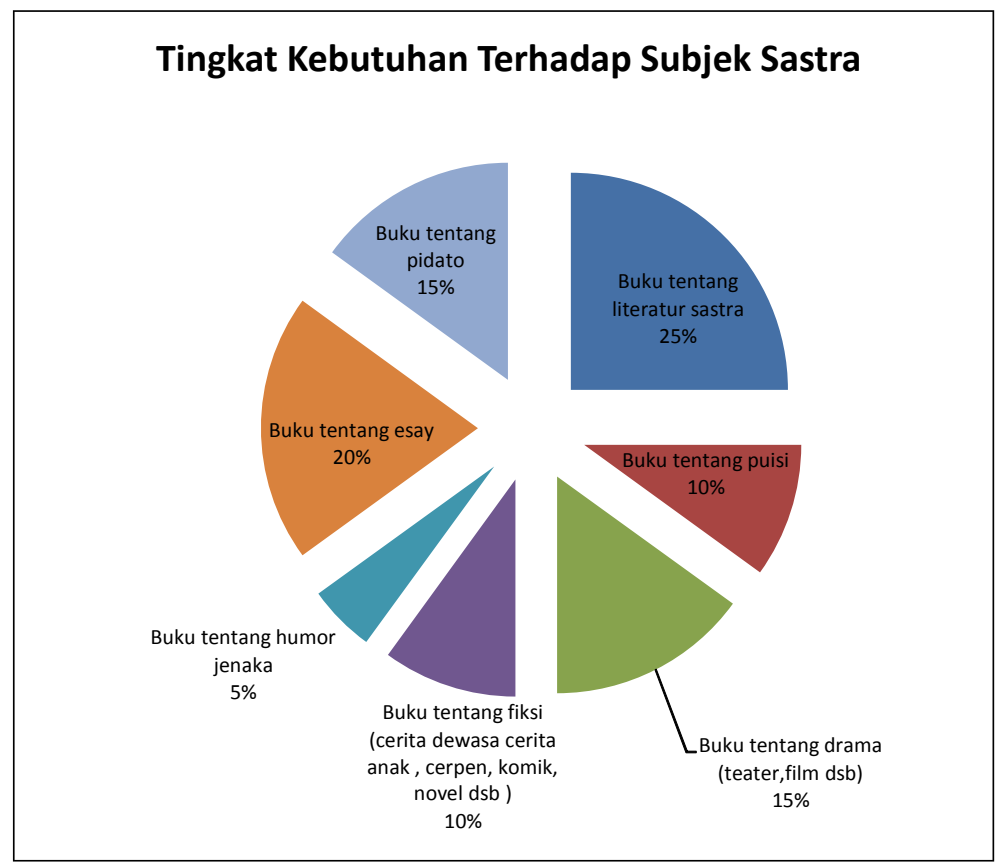

Diagram 10. Tingkat Kebutuhan Terhadap Subjek Sastra

\subsubsection{Tingkat Kebutuhan Subjek Sejarah}

Subjek Sejarah melingkupi beberapa sub subjek, dengan tingkat kebutuhan tertinggi pada buku-buku tentang seni lukisan sebanyak 23 persen (\%). Urutan kedua searah jarum jam adalah buku tentang Geografi dan Travel sebanyak 11 persen (\%), setara dengan itu dapat diuraikan sebagai berikut: a. Buku tentang Biografi, Autobiografi dan silsilah

b. Buku tentang Sejarah dunia kuno

c. Buku tentang Sejarah Negara-negara Asia

d. Buku tentang Sejarah Negara-negara lainnya Urutan ketiga, adalah buku-buku tentang Sejarah Negara-negara Afrika dan Amerika sebesar 6 persen (\%) dan terendah pada buku-buku tentang sejarah Negara-negara Eropa sebesar 5 persen (\%). 


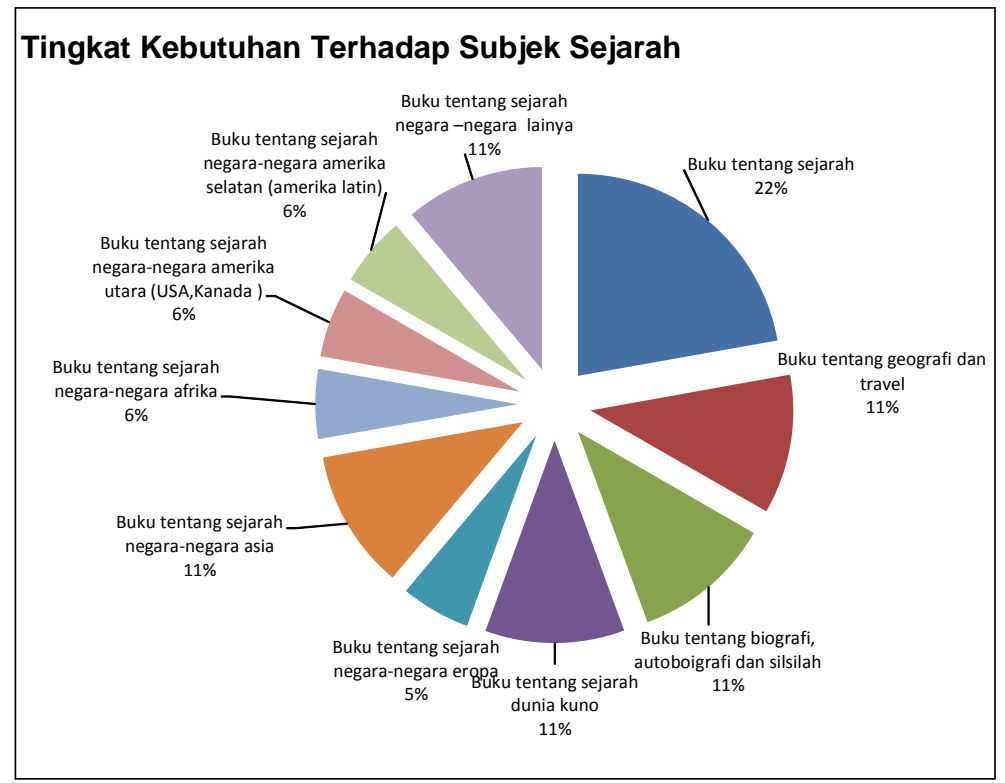

Diagram 11. Tingkat Kebutuhan Terhadap Subjek Sejarah

\section{KESIMPULAN}

Beberapa hal yang dapat disimpulkan dari kegiatan evaluasi koleksi ini, adalah:

1. Subjek yang dimiliki dan dibutuhkan pada tahun 2019 dibagi menjadi 10 subjek, yaitu:

a. Karya Umum

b. Subjek Filsafat dan Psikologi

c. Subjek Agama

d. Subjek Sosial

e. Subjek Bahasa

f. Subjek IImu Pengetahuan Alam dan Matematika

g. Subjek Teknologi dan IImu Terapan

h. Subjek Seni

i. Subjek Sastra

j. Subjek Sejarah

2. Tingkat kebutuhan subjek pada tahun 2019 , adalah sebagai berikut:

a. Tingkat kebutuhan tertinggi karya umum pada majalah dan jurnal sebesar 28 persen (\%) dan terendah buku-buku tentang fakta sebesar 4 persen (\%).

b. Tingkat kebutuhan tertinggi subjek Filsafat dan Psikologi pada buku-buku tentang psikologi pada buku-buku tentang psikologi, sebesar 31 persen $(\%)$ dan terendah adalah buku-buku tentang epistemologi sebanyak 6 persen (\%), sementara tentang metafisika, meski tersedia belum ada yang berminat.

c. Tingkat kebutuhan terhadap subjek Agama adalah pada buku-buku Agama Islam sebesar 75 persen (\%) sedangkan terendah adalah Agama Kristen sebesar 25 persen (\%), sementara diluar pemeringkatan buku-buku tentang Agama Islam dan Kristen, belum dimanfaatkan, seperti buku-buku tentang Agama Katolik, Budha dan Hindu.

d. Tingkat kebutuhan tertinggi subjek Sosial pada buku-buku tentang Administrasi Bisnis sebesar 17 persen (\%) dan terendah adalah ilmu kemiliteran sebesar 6 persen (\%) dari subjek lainnya yang setara.

e. Tingkat kebutuhan tertinggi subjek Bahasa pada buku-buku tentang ilmu Bahasa Inggris sebesar 23 persen (\%) dan terendah adalah etimologi sebesar 4 persen (\%).

f. Tingkat kebutuhan tertinggi Subjek IImu Pengetahuan Alam dan Matematika pada bukubuku tentang Biologi sebesar 15 persen (\%), terendah pada ekologi dan geologi sebanyak 8 persen (\%).

g. Tingkat kebutuhan tertinggi Subjek Teknologi dan IImu Terapan pada buku-buku tentang pertanian, peternakan dan ilmu terapan lainnya sebesar 24 persen (\%) dan terendah pada buku-buku tentang ilmu rekayasa, manajemen dan Public Relations, sebesar 7 persen (\%). Sementara buku-buku tentang keterampilan dan manajemen rumah tangga belum diminati.

h. Tingkat kebutuhan tertinggi Subjek Seni adalah pada buku-buku tentang seni lukisan sebanyak 23 persen (\%) dan terendah pada buku-buku tentang landscaping, seni dekoratif dan seni grafis sebanyak 4 persen (\%). Sementara buku-buku tentang seni patung, keramik dan logam belum diminati.

i. Tingkat kebutuhan tertinggi Subjek Sastra adalah pada buku-buku tentang literatur sastra sebanyak 25 persen (\%) dan terendah pada 
buku-buku tentang humor jenaka sebanyak 4 persen (\%).

c. Tingkat kebutuhan tertinggi Subjek Sejarah adalah pada buku-buku tentang Sejarah sebanyak 22 persen (\%) dan terendah pada buku-buku tentang Sejarah Negara-negara Eropa sebanyak 5 persen (\%).

3. Langkah-langkah yang dilakukan dalam mengembangkan metode evaluasi koleksi adalah: a. Menentukan Tim Evaluasi Koleksi

b. Menentukan Subjek yang dimiliki dan dibutuhkan

c. Menyeleksi serta mempertimbangkan subjek

d. Pengelompokan hasil koleksi berdasarkan subjek yang ditentukan dan membuat kuesioner tingkat kebutuhan subjek dan menyebarkannya

e. Melakukan penghitungan tingkat kebutuhan subjek

\section{SARAN}

Beberapa hal yang direkomendasikan dari kegiatan evaluasi koleksi ini, adalah:

1. Agar perpustakaan melakukan survey kebutuhan koleksi setiap tahun akademik

2. Agar perpustakaan menyediakan koleksi berkaitan dengan subjek teknologi dan ilmu terapan, yang terdiri dari buku-buku tentang pertanian, peternakan dan ilmu terapan lainnya, teknik kimia, teknologi, teknik manufaktur, kedokteran dan kesehatan, ilmu rekayasa, manajemen dan Public Relations, keterampilan dan manajemen rumah tangga

\section{DAFTAR PUSTAKA}

Perpustakaan Nasional RI. 2013. Revisi Pedoman Pengelolaan Koleksi Perpustakaan Perguruan Tinggi. Jakarta: Perpusnas RI

Perpustakaan Nasional RI. 2014. Instrumen Akreditasi Perpustakaan Perguruan Tinggi. Jakarta: Perpusnas RI

Sugiyono. 2008. Metode Penelitian Pendidikan: Penelitian Kuantitatif \& Kualitatif, dan R\&D. Bandung: Alfabeta.

Suwarno, Wiji. 2010. Pengetahuan Dasar Kepustakaan. Bogor: Ghalia Indonesia.

Tim Penyusun Kamus Pusat bahasa.2005. Kamus Besar Bahasa Indonesia.Jakarta: Balai Pustaka.

Tohirin.2012. Metode Penelitian Kualitatif dalam Pendidikan dan Bimbingan Konseling. Jakarta: Rajawali Pers.

Yaya, Suhendar. [s.y]. Pedoman Katalogisasi: Cara Mudah Membuat Katalog Perpustakaan).Jakarta: Rineka Cipta.

www.pnri.go.id, Peraturan Kepala Perpustakaan Nasional nomor 13 tahun 2017 diunduh pada bulan Mei 2018 